Proc. Estonian Acad. Sci. Geol., 1998, 47, 1, 31-44

\title{
HOLOCENE ENVIRONMENTAL EVENTS IN THE VIITNA AREA, NORTH ESTONIA
}

\author{
Leili SAARSE, Anneli POSKA, Enn KAUP, and Atko HEINSALU
}

Institute of Geology at Tallinn Technical University, Estonia pst. 7, EE-0001 Tallinn, Estonia; e-mail: saarse@gi.ee,poska@gi.ee,kaup@gi.ee

Received 7 October 1997

\begin{abstract}
Holocene vegetation dynamics of the Viitna kame field is discussed. Replacement of birch woods which dominated in the area at the beginning of the Holocene by mixed and broadleaved forest took place at c. $7600 \mathrm{BP}$, showing some delay in comparison with the other newly studied sites of Estonia. The elm decline at $4700 \mathrm{BP}$ occurred earlier than the general opening up of the area and possible pastoral farming which began c. $4000 \mathrm{BP}$. At $3300 \mathrm{BP}$, the first cereal pollen appears and the arable farming is suggested in the surroundings of the kame field. The kame field differs from the other parts of coastal Estonia in a low share of pine trees in forests. Hence, these forests were less vulnerable to fires, especially in the Early Holocene. Pine became an important component in the forest composition rather late, during the last 1500 years.

Lake-level fluctuations in four investigated lakes (Viitna Lina- and Pikkjärv, Nabudi, and Vohnja Kõverjärv) were reconstructed mostly on the basis of changes in the sediment composition at least on one transect and aquatic pollen. All the studied lakes had the lowest water level between 5400-3700 BP, which was 3-4.5 m lower than at present. This regional lowering was caused by the ground water table drop due to the formation of the Loobu River.

The pollen-based climate reconstruction shows a rapid warming and an increase in humidity at the end of the Pre-Boreal. Climate deteriorated between 8700-8500, 7900-7700, 2000-1000, and 500-300 BP. Shifts to wetter conditions appeared at 9200-8800, 7800-7600, 6500-6300, 5800$5200,4600-3900,2400-1600$, and 800-600 BP.
\end{abstract}

Key words: pollen, radiocarbon dates, vegetation history, climate and lake-level changes, Holocene.

\section{INTRODUCTION}

The main objective of the present study is to examine the Holocene vegetation dynamics in a forested area, to reconstruct the event stratigraphy, and to establish the trend of climate and lake-level fluctuations. Lakes respond to the 
fluctuations in the local hydrologic balance by changes in depth and area. Records of these changes are commonly printed in sediment lithology, microand macroremains, and shorelines. Lake-level fluctuations serve as a useful tool for the moisture balance control (Harrison et al., 1991). Closed kettle lakes have been taken as the ideal for lake-level reconstruction (Street-Perrot \& Harrison, 1985). In several earlier studies the effect of ground water has been ignored. Numerous closed lakes on the outwash plains and kame fields have their water tables closely connected with the ground water regime (Digerfeldt et al., 1992).

In 1996 the project "Postglacial natural and anthropogenic changes in Estonia: the biostratigraphical and hydrogeoecological approach" was initiated and the Viitna-Uku kame field (Fig. 1) was selected as the natural key area for the study. The Loobu River valley divides the Viitna and Uku kame fields into two parts. Finds of the peaty interlayer, intercalated into gyttja in Lake Viitna Linajärv (also Linajärv), mossy gyttja horizon in Lake Viitna Pikkjärv (also Pikkjärv), and basal woody peat below gyttja in Lake Vohnja Kõverjärv (also Kõverjärv) (Saarse, 1994) encouraged our selection.

Both Viitna Pikk- and Linajärv have earlier been studied biostratigraphically, however, the pollen diagrams by $\mathrm{R}$. Pirrus have not been published. The only diagram available on the Viitna kame field comes from the little kettle hole southwest of Pikkjärv (Koff, 1984). This diagram is supplemented by four radiocarbon dates, but shadowed by local and extralocal pollen composition. The studies on the Loobu River valley showed the existence of two dammed lakes on the upper course of the river valley. In Vatku, the northernmost of these lakes, a peat layer occurred below the limnic deposits (Männil, 1961).

\section{METHODS}

Four transects with 55 cores have been carried out on Viitna Pikkjärv and 11 cores on Kõverjärv (Saarse, 1994). In winter 1996, additionally one core from Pikkjärv and one from Kõverjärv were taken and subsampled at $1 \mathrm{~cm}$ intervals for pollen, bulk organic matter, inorganic matter, and carbonate content. All corings were made using a Belarus peat sampler.

For pollen preparation and analysis a standard method described by Erdtman (1936) and Fægri \& Iversen (1989) was used, c. 1000 AP (arboreal pollen) was counted at each level. The percentage calculations were based on the sum of terrestrial pollen. The percentages of other microfossils were calculated from the basic pollen sum. All diagrams were plotted using TILIA and TILIA graph programs (Grimm, 1992).

The organic matter content was presumed to be the loss-on-ignition at $550^{\circ} \mathrm{C}$. For conventional radiocarbon dates, a $10 \mathrm{~cm}$ sediment interval was subsampled. The age measurements were made from bulk samples at the laboratory of the Institute of Geology, Tallinn. Conventional radiocarbon dates were used in discussion. For climate reconstruction the APOLLINAIRE program of Guiot (1987) was applied. 


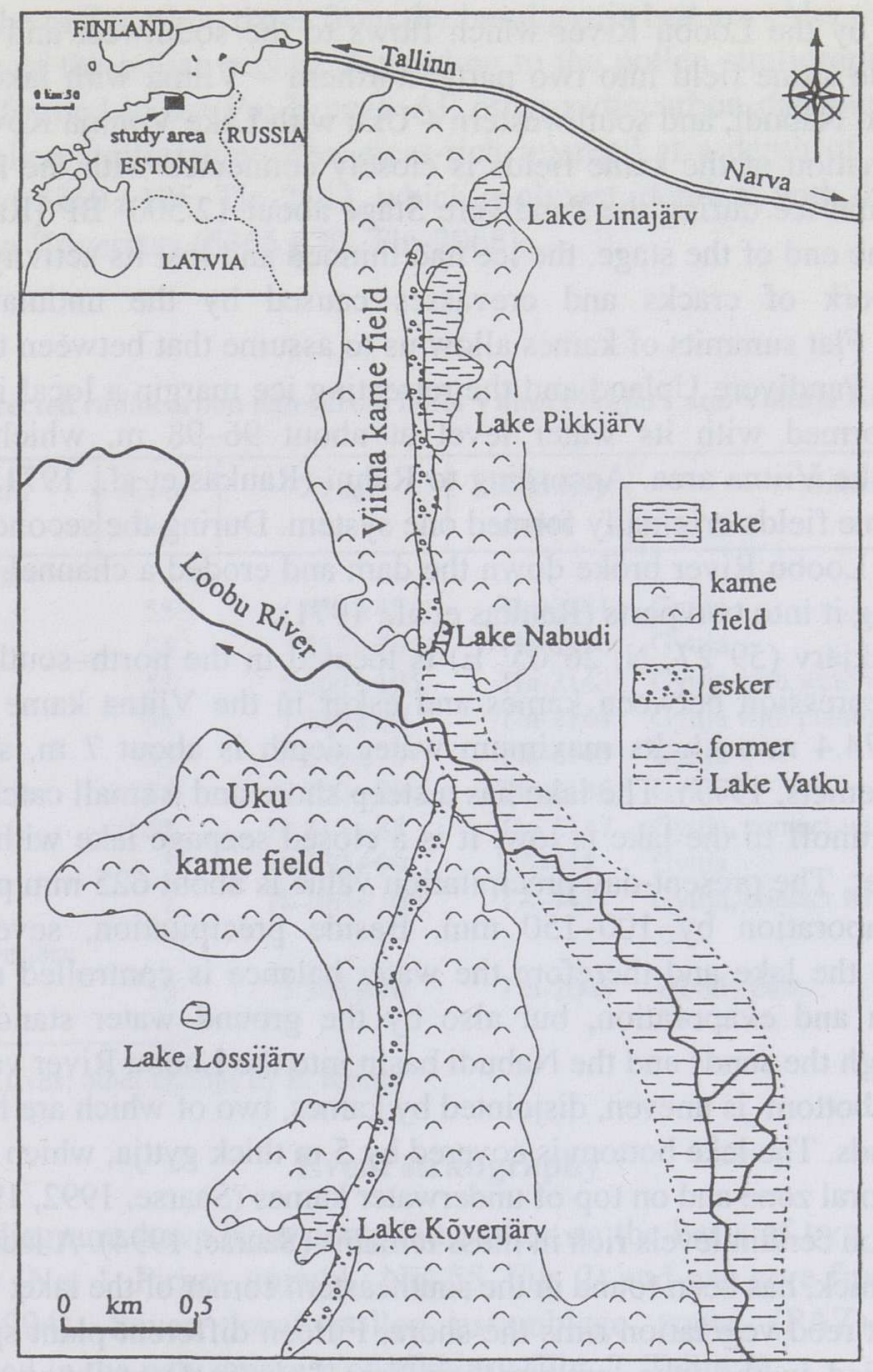

Fig. 1. Viitna and Uku kame fields.

\section{MATERIAL}

\section{Geological setting}

The Viitna and Uku kame fields are located on the northwestern slope of the Pandivere Upland. They are composed of hills, cupolas, ridges, and flat-topped kames rising up to $98 \mathrm{~m}$ a.s.l. (Raukas et al., 1971; Saarse, 1987, 1992, 1996). Kames alternate with dead-ice hollows of glaciokarst origin, four of which are occupied by lakes (Fig. 1). Smaller kettle holes are filled with peat deposits (Koff, 1984). The surface of the kame fields grades to the north. The kame fields 
are drained by the Loobu River which flows to the southwest and divides the once a single kame field into two parts: northern - Viitna with lakes Pikkjärv, Linajärv, and Nabudi, and southwestern - Uku with Lake Vohnja Kõverjärv.

The formation of the kame fields is closely connected with the recession of the continental ice during the Pandivere Stage about 12500 BP (Raukas et al., 1971). By the end of the stage, the ice had thinned and lost its activity due to the dense network of cracks and crevasses caused by the undulated bottom topography. Flat summits of kames allow us to assume that between the northern slope of the Pandivere Upland and the retreating ice margin a local ice dammed lake was formed with its water level at about 96-98 m, which obviously submerged the Viitna area. According to Rähni (Raukas et al., 1971) the Viitna and Uku kame fields originally formed one system. During the second half of the Atlantic the Loobu River broke down the dam and eroded a channel through the sand dividing it into two parts (Raukas et al., 1971).

Lake Pikkjärv $\left(59^{\circ} 27^{\prime} \mathrm{N}, 26^{\circ} 05^{\prime} \mathrm{E}\right)$ is located in the north-south orientated ice-block depression between kames and esker in the Viitna kame field at an altitude of $74.4 \mathrm{~m}$ a.s.1. Its maximum water depth is about $7 \mathrm{~m}$, surface area 16.3 ha (Mäemets, 1977). The lake has a steep shore and a small catchment area. Hence, the runoff to the lake is low. It is a closed seepage lake without surface inlet or outlet. The present-day precipitation value is about $625 \mathrm{~mm}$ per year and exceeds evaporation by $100-150 \mathrm{~mm}$. Beside precipitation, several bottom springs feed the lake and therefore the water balance is controlled not only by precipitation and evaporation, but also by the ground water stand. The lake drains through the sands and the Nabudi basin into the Loobu River valley.

The lake bottom is uneven, disjointed by kames, two of which are high enough to form islands. The lake bottom is covered by $5 \mathrm{~m}$ thick gyttja, which is absent in the steep littoral zone and on top of underwater kames (Saarse, 1992, 1994). Gyttja is colloidal, on certain levels rich in moss remains (Saarse, 1994). A lacustrine lime bed, $25 \mathrm{~cm}$ thick, has been found in the southeastern corner of the lake.

Emergent reed vegetation rims the shore. Fifteen different plant species have been identified in the lake, among them rare Lobelia Dortmanna and Isoëtes lacustris (Mäemets, 1968). At present, the pine and spruce are predominating in the area. The kame field is practically unpopulated due to the irregular complicated topography and unproductive Podzols.

Lake Vohnja Kõverjärv $\left(59^{\circ} 26^{\prime} \mathrm{N}, 26^{\circ} \mathrm{E}\right)$ is located in the Uku kame field at an altitude of $89.7 \mathrm{~m}$ a.s.1. Its surface area is 2.9 ha, maximum water depth $4.5 \mathrm{~m}$ (Mäemets, 1977). It is a closed lake with high northern and eastern shores and terrestrificated southern and western shores. The bottom of Kõverjärv is covered by 1-2 $\mathrm{m}$ thick deposits of woody peat and gyttja (Saarse, 1994).

\section{Chronology}

The chronology of Pikkjärv is based on seven radiocarbon dates from core No. 55 (Table 1). Two dates have been obtained earlier from core No. 1 (Pirrus, 
unpubl.). The radiocarbon dates from the basal gyttja bed are older than expected on the base of the pollen record. According to the pollen stratigraphy, the basal gyttja was formed in the Pre-Boreal. All other radiocarbon dates are consistent with the pollen stratigraphy. The moss-rich interbed at a depth of $610-620 \mathrm{~cm}$ was dated to $5360 \pm 105$, Tln-2143, which is almost identical with the age of the basal peat in Kõverjärv (5365 \pm 70 , Tln-2068).

Table 1

Uncorrected radiocarbon dates from lakes Viitna Pikkjärv and Vohnja Kõverjärv

\begin{tabular}{l|c|c|c|l}
\hline \multicolumn{1}{c|}{ Depth, cm } & $\begin{array}{c}\text { Core } \\
\text { No. }\end{array}$ & ${ }^{14}$ C age & $\begin{array}{c}\text { Laboratory } \\
\text { index }\end{array}$ & Material \\
\hline Viitna Pikkjärv & \multicolumn{3}{c}{ Tln-2141 } & Gyttja \\
$490-500$ & 55 & $650 \pm 45$ & Tln-2140 & Gyttja \\
$540-550$ & 55 & $3755 \pm 70$ & Th-2143 & Gyttja with watermoss \\
$610-620$ & 55 & $5360 \pm 105$ & Tln \\
$690-700$ & 55 & $7320 \pm 60$ & Tln-2144 & Gyttja with plant macroremains \\
$772-782$ & 55 & $8610 \pm 70$ & Tln-2145 & Gyttja \\
$792-802$ & 55 & $9200 \pm 70$ & Tln-2146 & Gyttja \\
$812-822$ & 55 & $10515 \pm 85$ & Tln-2147 & Gyttja, contact with sand \\
$830-840 *$ & 1 & $8350 \pm 90$ & TA-444 & Gyttja \\
$840-850 *$ & 1 & $10690 \pm 100$ & TA-443 & Gyttja, contact with sand \\
Vohnja Kõverjärv & & & & \\
$430-440$ & 10 & $5365 \pm 70$ & Tln-2068 & Woody peat
\end{tabular}

* dated by E. Ilves; other datings by E. Kaup.

\section{Event stratigraphy}

Pollen diagrams have been compiled earlier on the basis of two nearby cores in Pikkjärv (No. 1; Pirrus, unpubl.; No. 55, Fig. 2) and one core from Kõverjärv (Saarse, 1994). Seven local pollen assemblage zones (PAZ) have been distinguished in the new diagram of Pikkjärv (Fig. 2, Table 2).

Table 2

Local pollen assemblage zones and their chronology

\begin{tabular}{l|l}
\hline \multicolumn{1}{c|}{ Local PAZ } & Approximate ${ }^{14}$ C age, BP \\
\hline Vi-1 Betula & $9500-9000$ \\
Vi-2 Alnus-Ulmus-Corylus & $9000-8000$ \\
Vi-3 Ulmus-Corylus-Tilia & $8000-6500$ \\
Vi-4 Tilia-Corylus-Ulmus-Fraxinus & $6500-5000$ \\
Vi-5 Quercus-Picea & $5000-4000$ \\
Vi-6 Picea & $4000-2500$ \\
Vi-7 Betula-Pinus-Picea & $2500-0$
\end{tabular}




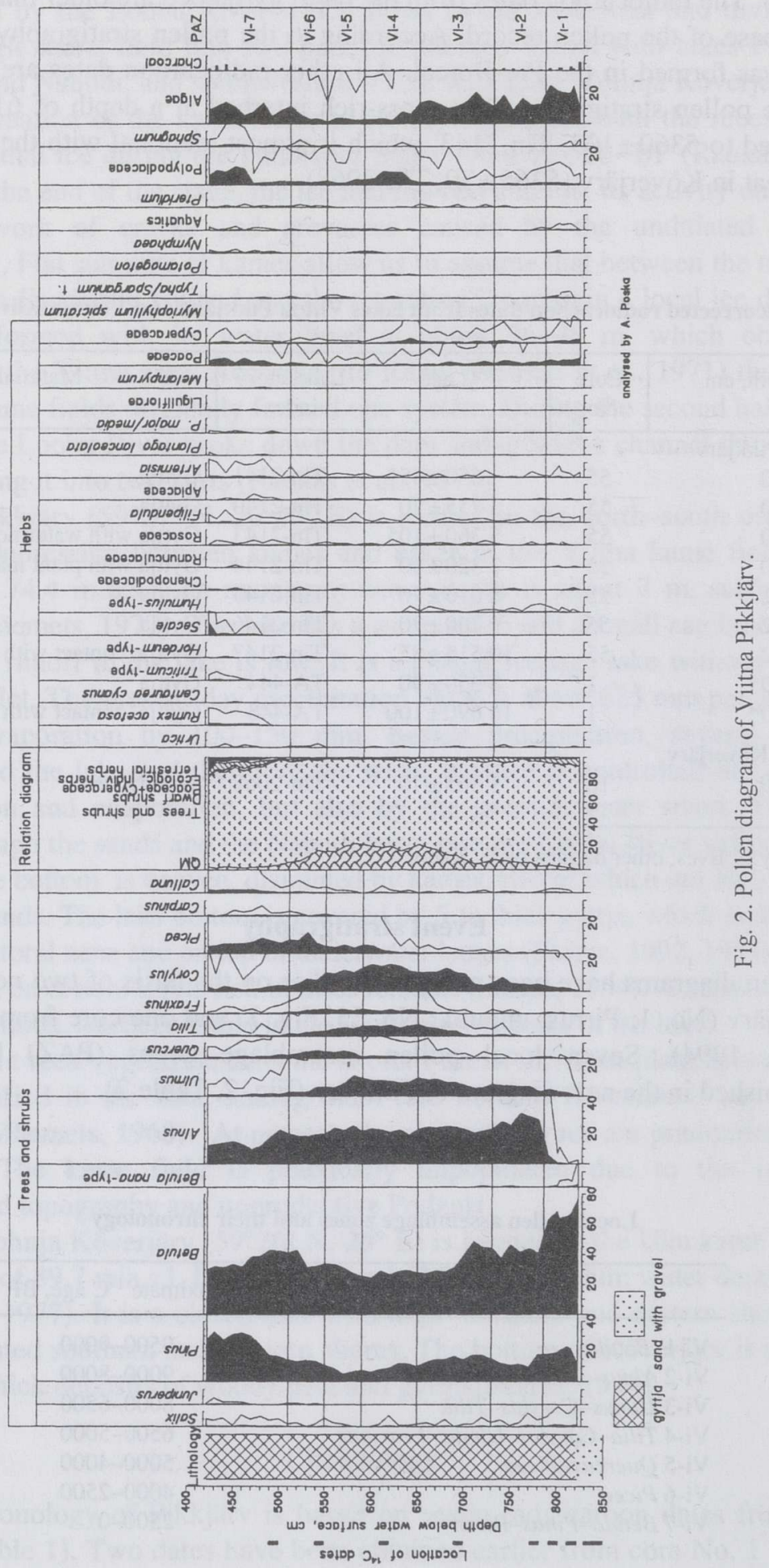


Main events of the vegetation history of the Viitna area are known from earlier studies (Pirrus, unpubl.; Koff, 1984; Saarse, 1992, 1994, 1996), but they are insufficiently dated. Seven new radiocarbon dates from Pikkjärv allow us to establish a reliable chronostratigraphy and estimate the age of main biostratigraphical events. However, the basal ${ }^{14} \mathrm{C}$ dates $(10690 \pm 100$, TA-443 and $10515 \pm 85$, Tln-2147) are open to discussion, as they are both beyond the Betula PAZ upper limit.

\section{DISCUSSION}

\section{Vegetation events}

The forest development in the area was initiated by birch, to some extent assisted by pine. Betula pollen values reach a maximum before $9000 \mathrm{BP}$ in Vi-1 PAZ (Fig. 2). Due to its high competitiveness on sandy and peaty soils which are widespread in the area, birch maintained an important role in the composition of vegetation throughout the Holocene. With alder immigration and quick spread at c. $8900 \mathrm{BP}$ (Vi-2 PAZ), birch got a competitor for habitat and was pressed back a little, but still maintained its position as a dominant tree species in the area. Some decrease in birch is traceable during the maximal spread of broad-leaved trees (7600-2700 BP). The changes in the Alnus pollen curve are rather small, with some decline at 2000-1200 BP and stabilization at lower values after that (Vi-7 PAZ). The share of pine is low throughout the Holocene. During the last 1500 years (Vi-7 PAZ), the importance of pine increased at the expense of alder and birch. Hazel and elm immigrated to the area at the end of the Pre-Boreal and expanded slowly further on. The pollen curves of Corylus and Ulmus have similar development with a significant decline between $8300-8000$ BP. The pollen curves of Tilia, Quercus, and Fraxinus start at about $8400 \mathrm{BP}$, but reach their rational limits c.1000 years later. Hazel, elm, and lime reach maximal distribution in the area $c$. 6300-6200 BP. The elm decline is sharp at $4700 \mathrm{BP}$, however, no human activity is recorded in the area at that time. The expansion of oak was pressed back up to c. $4700 \mathrm{BP}$, probably due to the lack of suitable growing sites. Oak spread afterwards at the expense of other broad-leaved trees and reached its maximum at 3600 BP. Scattered records of Carpinus pollen appear from c. $4000 \mathrm{BP}$ with a slight peak at $1400 \mathrm{BP}$ and may indicate opening up of the former dense forest cover and the growth of secondary woodland (Greig, 1996). Spruce arrived into the area at c. 8000 BP, expanded at c. $5500 \mathrm{BP}$, and reached its first maximum at $3200 \mathrm{BP}$ and the second one at c. $1300 \mathrm{BP}$.

\section{Human impact events}

Indications of prehistoric human impact in the area are weak through the Holocene. Some traces of disturbance in the natural forest development appear 
c. 7600-8000 BP as most of trees, especially broad-leaved ones, decline. Still, as the other human impact indicators are missing, connection of this event with activities of man in the area is questionable and the influence of natural factors such as climate and water balance must be taken into consideration. Soon after the elm decline, about $4000 \mathrm{BP}$, the amount of total tree pollen decreases, Artemisia and Poaceae pollen increases. The Calluna curve, which rises moderately at the main clearance horizon and more expressively at the phase of intense cereal growing, evidences of the heath development. The land in the surroundings was apparently used for pasturing, which is traceable on the pollen diagram by finds of Juniperus pollen and increase in Urtica, Poaceae, and Apiaceae. Pteridium spores form a continuous curve since 3800 BP simultaneously with the rise of the charcoal curve. The first occasional cereal pollen grains (Hordeum) identified at c. $3300 \mathrm{BP}$ show that crop farming was also practised in the surroundings. Hordeum is followed by Triticum (2900 BP) and Avena (2500 BP) pollen finds. The consistent curve of Rumex acetosella starts $c .1400 \mathrm{BP}$ and the Secale cereale curve from $c .1100 \mathrm{BP}$. A reduction of cereal cultivation $c .700 \mathrm{BP}$ is followed by an increase in agriculture, especially during the last 300 years. Soil erosion has been increasing rapidly from $c .3750$ $\mathrm{BP}$, being more intensive during the last 1000 years (Fig. 3).

\section{Hydrological events}

The following lake-level fluctuations have been reconstructed.

1. Low lake level (phase 1) in the Early Pre-Boreal, recorded as a hiatus at the sampling point in Lake Pikkjärv (core 55), sand sedimentation in profile 1 (Pirrus, unpubl.), and peat formation in Vatku dammed lake (Männil, 1961).

2. Rising lake level (phase 2) in the Late Pre-Boreal and Boreal. In lakes Viitna Pikk- and Linajärv highly organic gyttja, in Lake Kõverjärv coarse detritus gyttja started to deposit (Saarse, 1994), in Vatku dammed lake limy gyttja and lacustrine lime deposited, covering transgressively the peat.

3. High lake level (phase 3 ) in the Atlantic chronozone. In all studied lakes gyttja accumulated with high increment.

4. Low lake-level stand (phase 4) at about 5400-3700 BP. Owing to the high water stand in the Atlantic, Vatku dammed lake reached the threshold level and began to overflow, eroding the valley into soft sandy deposits. The wide terrace at $75 \mathrm{~m}$ a.s.1. could mark the elevation of water level in the lake before its drainage. The threshold of Vatku dammed lake lowered and finally the lake drained dry giving a start to the Loobu River. Because of such abrupt drainage the ground water table locally lowered, causing lake-level drop by about $3 \mathrm{~m}$ in Viitna Linajärv, by $3.5 \mathrm{~m}$ in Pikkjärv. The greatest lowering is registered in Kõverjärv, which is located farthest from the river that drains the kame field. This event has clear imprints in the sediment stratigraphy. In Pikk- and Linajärv gyttja enriched with water moss began to accumulate; in the littoral zone of Lina- and Kõverjärv even peat accumulated. The bottom of Vatku dammed lake 


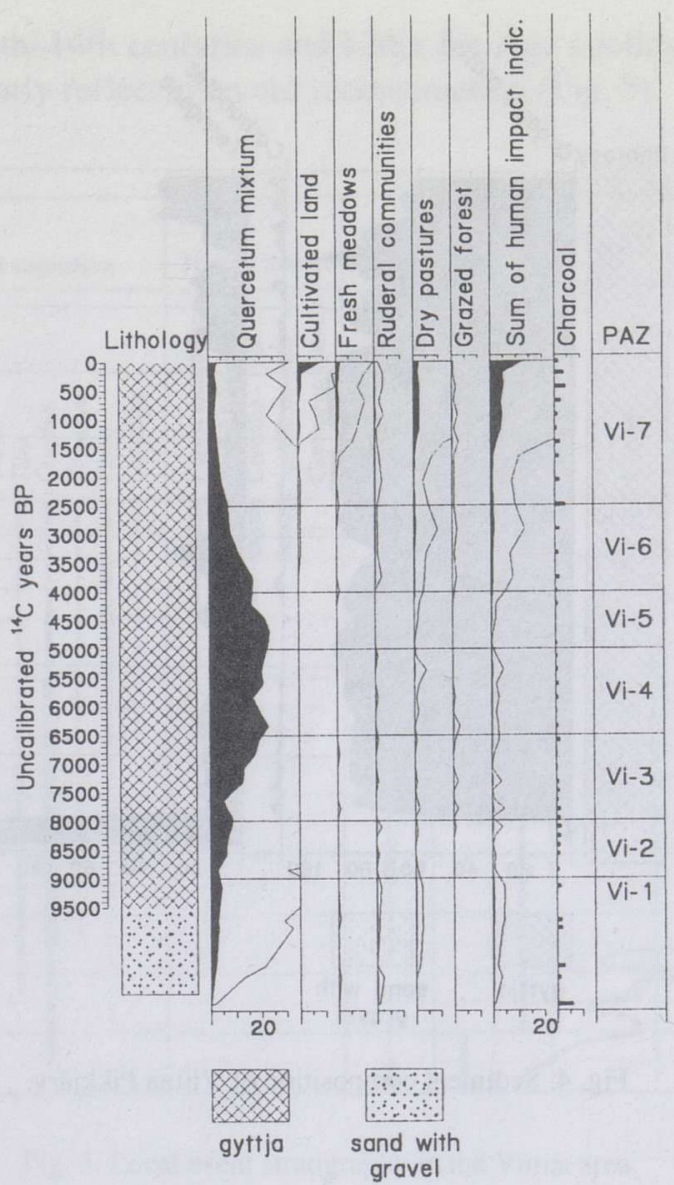

Fig. 3. Human impact diagram of Viitna Pikkjärv.

started to paludify. Radiocarbon dates of the mossy gyttja bed in Pikkjärv $(5360 \pm 105)$ and buried peat in Kõverjärv (5365 \pm 70$)$ are almost identical and fix the age of the drainage of Vatku dammed lake and the formation of the Loobu River.

5. Increasing lake level since the Late Sub-Boreal (phase 5). In the Late SubBoreal, the lakes in the vicinity of Viitna show a tendency to rise, in contrast to the other lakes where the lowering was suggested (Saarse, 1987; Saarse \& Harrison, 1992). Highly organic gyttja accumulated in lakes with scanty aquatic pollen. Since $3750 \mathrm{BP}$, the terrigenous fraction considerably increased in sediments (Fig. 4) due to erosion and obviously lake-level rise (Fig. 5). 


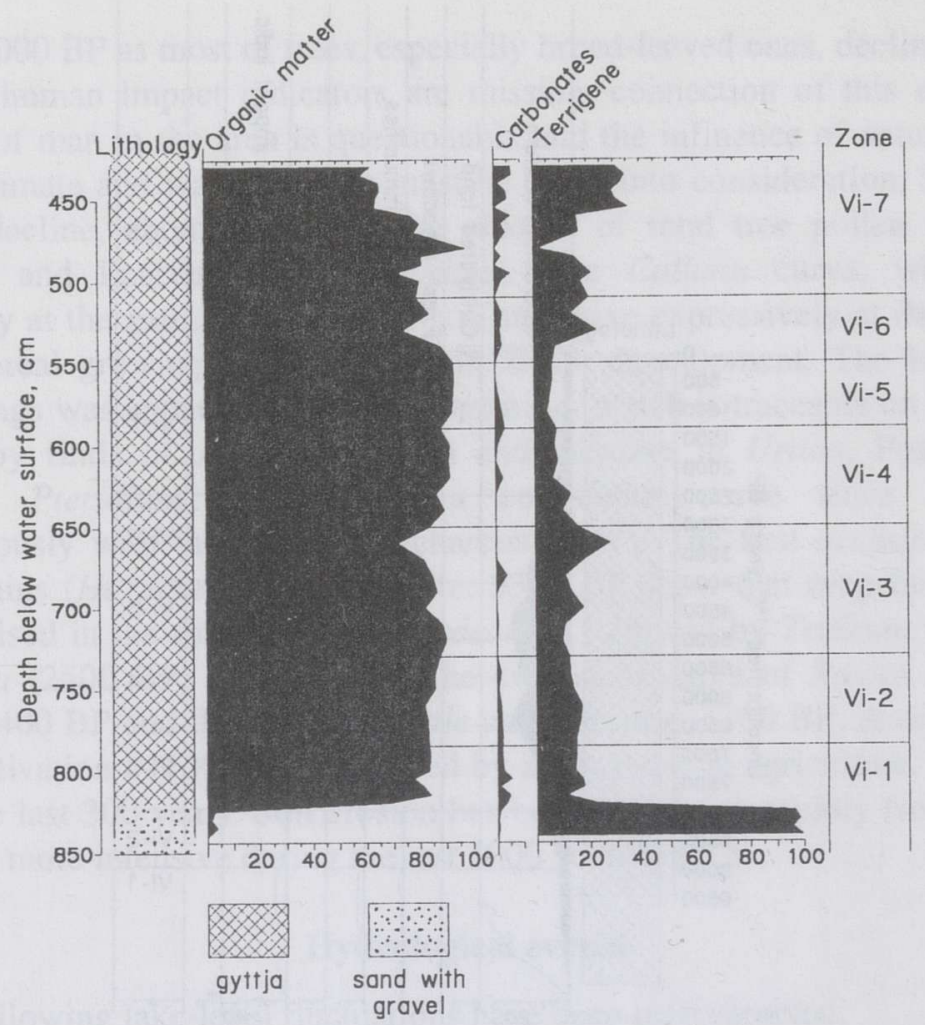

Fig. 4. Sediment composition of Viitna Pikkjärv.

\section{Climatic events}

Climate reconstruction displays a rapid warming and an increase in humidity during the Pre-Boreal (Fig. 5). In the middle of the Boreal, the climate shortly deteriorated, mostly at the expense of the cooling in wintertime. The contrast between summer and winter temperatures was high, which made the climate more continental. At the end of the Boreal, the climatic conditions improved, but deteriorated again about 7900-7700 BP, before the final amelioration in the Atlantic. The warm and humid climate is characteristic of the Atlantic and the Early Sub-Boreal. The highest July temperature has been estimated for 6100 $4900 \mathrm{BP}$ and highest winter temperatures for 4400-3700 BP. Summer and winter temperatures as well as precipitation values surpassed the present-day values. Since $3700 \mathrm{BP}$ onwards the annual temperature decreased once again, mostly on account of cooler winters. Between 3700-2500 BP, the winter temperature decreased by almost one degree, but the summers remained considerably warm. The Sub-Atlantic chronozone (2500 BP up to the present) is characterized by increasing continentality. About 2500-2000 BP, climate shortly improved, but then turned cooler again. The last trend was interrupted by the Medieval 
warming in the 11th-14th centuries and Little Ice Age cooling in the 15th-17th centuries, both clearly reflected on our reconstruction (Fig. 5).

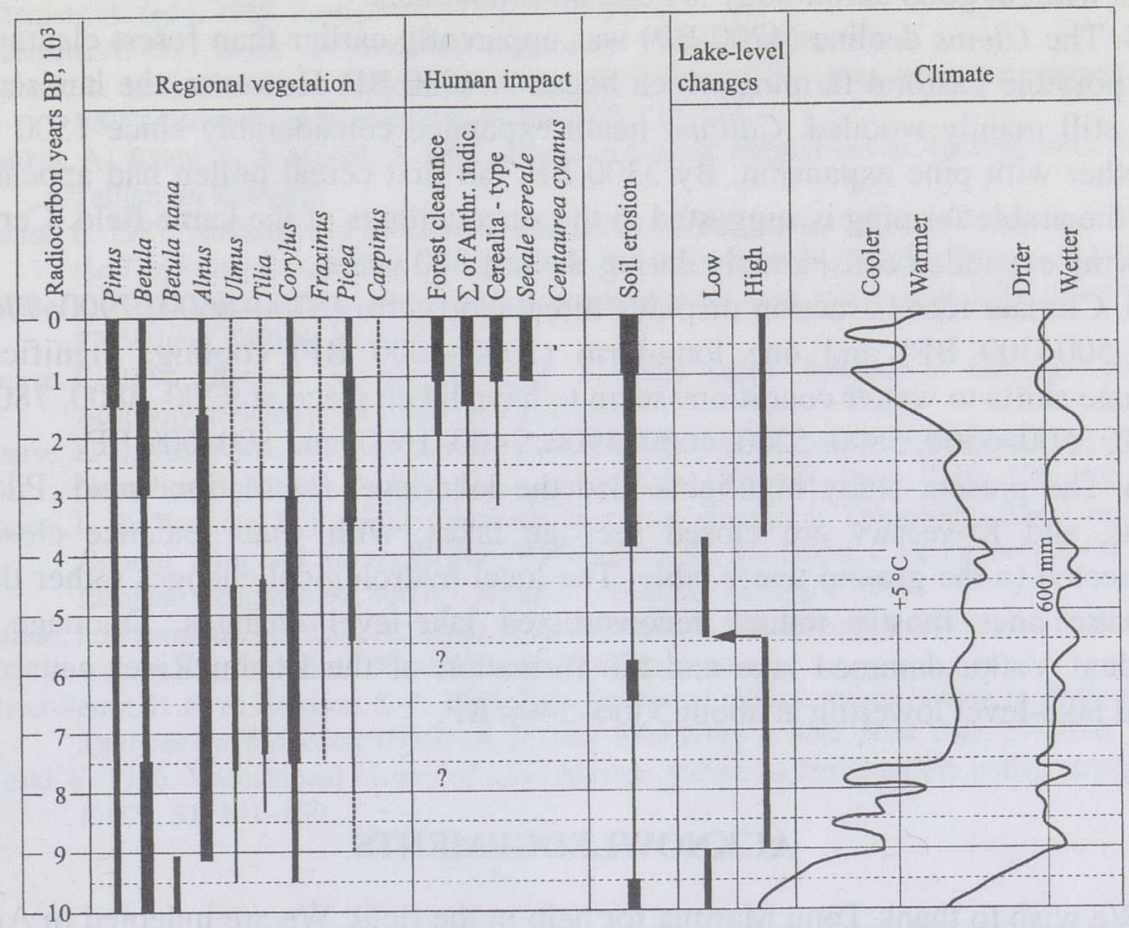

Fig. 5. Local event stratigraphy in the Viitna area.

\section{CONCLUSIONS}

1. The study area experienced considerable environmental changes during the Holocene. The predominant woodland vegetation in the early Holocene up to 9000 BP was of Betula, and Alnus-Betula between 9000-7600 BP. However, variation from sequence to sequence exists (Pirrus, unpubl.; Koff, 1984). Most important vegetation changes appeared at $c .7600 \mathrm{BP}$ in Vi-3 PAZ, when the mixed and broad-leaved forest replaced the birch forest. This occurred with some delay in comparison with the alvar areas (Veski, 1996; Saarse et al., in press).

2. The Viitna area is characterized by a low share of Pinus pollen. Hence, the probability of the fires was low, especially in the Early Holocene. Pine became an important component in the forest composition rather late, during the last 1500 years.

3. In the Mid-Holocene closed woodland developed, dominated by Betula, Corylus, Ulmus, Tilia, and Fraxinus. Alnus was frequent around Viitna Pikkjärv. In the Early Sub-Boreal, the forest composition was enriched with Quercus and 
Picea. The broad-leaved forest dominated for about 3000 years, in the other mentioned sites for about 1000 years longer. It shows that the timing of palaeoecological events differs in different sites and their correlation over large areas without good chronology is quite questionable.

4. The Ulmus decline (4700 BP) was apparently earlier than forest clearance and possible pastoral farming which began $c .4000$ BP. However, the landscape was still mainly wooded. Calluna heath expanded considerably since $1500 \mathrm{BP}$ together with pine expansion. By $3300 \mathrm{BP}$, the first cereal pollen had appeared and the arable farming is suggested in the surroundings of the kame field. Cereal growing expanded considerably during the last 300 years.

5. Climate reconstruction displays three short-term (8700-8500, 7900-7700, and 500-300 BP) and one long-term (2000-1000 BP) cooling. Significant climate shifts to wetter conditions seem to have taken place at 9200-8800, 7800$7600,6500-6300,5800-5200,4600-3900,2400-1600$, and 800-600 BP.

6 . The present study highlights also the lake-level fluctuation trend. Pikk-, Lina-, and Kõverjärv are closed seepage lakes, with water balance closely connected to the ground water table. The local hydrological changes rather than climatic ones mostly induce reconstructed lake-level changes. Drainage of residual Vatku dammed lake and the formation of the Loobu River caused a rapid lake-level lowering at about 5360-5400 BP.

\section{ACKNOWLEDGEMENTS}

We wish to thank Tõnu Martma for help in the field. We are indebted to Anto Raukas and Avo Miidel for critical remarks on the manuscript. Financial support of the Institute of Geology and Estonian Science Foundation grant No. 1958 is appreciated.

\section{REFERENCES}

Digerfeldt, G., Almendinger, J. E. \& Björck, S. 1992. Reconstruction of past lake levels and their relation to groundwater hydrology in the Parkers Prairie sandplain, west central Minnesota. Palaeo., Palaeo., Palaeo., 94, 99-118.

Erdtman, G. 1936. New methods in pollen analysis. Sven. Bot. Tiddsskr., 30, 154-164.

Fægri, K. \& Iversen, J. 1989. Textbook of Pollen Analysis. John Wiley and Sons, Chichester.

Greig, J. 1996. Great Britain - England. In Palaeoecological Events During the Last 15000 Years (Berglund, B. E., Birks, H. J. B., Ralska-Jasiewiczowa, M. \& Wright, H. E., eds.). John Wiley \& Sons, Chichester, 15-76.

Grimm, E. 1992. TILIA and TILIA graph: Pollen spreadsheet and graphics program. In 8th International Palynological Congress. Program and Abstracts. Aix-en-Provence, France, 56.

Guiot, J. 1987. Late Quaternary climatic change in France estimated from multivariate pollen time series. Quat. Res., 28, 100-118.

Harrison, S. P., Saarse, L. \& Digerfeldt, G. 1991. Holocene changes in lake levels as climate proxy data in Europe. In Evaluation of Climate Proxy Data in Relation to the European Holocene (Frentzel, B., ed.). Paläoklimaforschung, 6, 159-169. 
Koff, T. 1984. O nekotorykh zakonomernostyakh formirovaniya sporovo-pyl'tsevykh spektrov v bolotakh i ozernykh otlozheniyakh (na primere rajona Viitna-Severnaya Estoniya). In Khronologiya $i$ formirovanie chetvertichnogo pokrova Estonii (Raukas, A., ed.). Institut Geologii AN ESSR, Tallinn, 37-50 (in Russian).

Mäemets, A. (ed.). 1968. Eesti järved. Valgus, Tallinn.

Mäemets, A. 1977. Eesti NSV järved ja nende kaitse. Valgus, Tallinn.

Männil, R. 1961. Pandivere kõrgustiku piirkonnas esinevaist Holotseensetest järvesetetest. Eesti NSV TA Geoloogia Instituudi uurimused VII, 115-133.

Raukas, A.; Rähni, E. \& Miidel, A. 1971. Marginal Glacial Formations in North Estonia. Valgus, Tallinn (in Russian).

Saarse, L. 1987. An outline of water-level changes in small Estonian lakes. In Palaeohydrology of the Temperate Zone II. Lakes (Raukas, A. \& Saarse, L., eds.). Valgus, Tallinn, 137-146.

Saarse, L. 1992. Viitna mõhnastiku ja järvede kujunemisest. Eesti Geograafia Seltsi Aastaraamat, 27. Valgus, Tallinn, 30-43.

Saarse, L. 1994. Bottom Deposits of Small Estonian Lakes. Institute of Geology, Estonian Academy of Sciences, Tallinn (in Russian).

Saarse, L. 1996. Viitna. In The Third Baltic Stratigraphic Conference (Meidla, T., Puura, I., Nemliher, J., Raukas, A. \& Saarse, L., eds.). Tartu University Press, Tartu, 139-142.

Saarse, L. \& Harrison, S. P. 1992. Holocene lake-level changes in the eastern Baltic region. In Estonia. Man and Nature (Kaare, T., Mardiste, H., Merikalju, L. \& Punning, J.-M., eds.). Estonian Geographical Society, Acad. Sci. Estonia, Tallinn, 6-20.

Saarse, L., Heinsalu, A., Poska, A., Veski, S. \& Rajamäe, R. Palaeoecology and human impact in the vicinity of Lake Kahala, North Estonia. PACT (in press).

Street-Perrot, F. A. \& Harrison, S. P. 1985. Lake levels and climate reconstruction In Palaeoclimate Analyses and Modelling (Hecht, A. D., ed.). John Wiley \& Sons, New York, 291-340.

Veski, S. 1996. Vegetational history of Lake Maardu sediments based on the pollen stratigraphy. PACT, 51, 141-150.

\title{
KESKKONNATINGIMUSTE HOLOTSEENSED MUUTUSED VIITNA ÜMBRUSES PÕHJA-EESTIS
}

\author{
Leili SAARSE, Anneli POSKA, Enn KAUP ja Atko HEINSALU
}

On käsitletud taimestiku muutusi Viitna ja Uku mõhnastikus. Varaholotseenis valdasid siin kasemetsad, mis umbes 7600 a.t. asendusid sega- ja laialehiste metsadega. Alvaritel toimus selline muutus juba boreaali lõpul. Mõneti ootamatu on männimetsade suhteliselt tagasihoidlik osakaal holotseeni alguses. Mänd muutus valdavaks puuliigiks umbes 1500 a.t. Esimesed inimmõju ilmingud on dateeritud 4000 a.t., esimesed kultuurkõrrelised ilmusid õietolmuspektritesse 3300 a.t., viidates põlluharimise algusele mõhnastiku lähistel.

Järvede veetaseme muutusi on uuritud nelja järve näitel. Siinsete järvede veetaseme kõikumine erineb oluliselt teiste järvede veetaseme muutustest. Alates preboreaalist kuni peaaegu atlantikumi lõpuni veetase tõusis. Selle tulemusel hakkas Vatku paisjärv voolama üle teda paisutanud mõhnade, erodeerides pudedatesse liivadesse Loobu oru. Umbes 5400 a.t. jooksid Loobu jõe ülemjooksul olnud paisjärved tühjaks. Jõe dreenival toimel alanes ka lähedalasuvate järvede veetase. Sellest annavad tunnistust samblarikkad kihid Pikk- ja 
Linajärves, basaalne turvas Kõverjärves ning Linajärve kaldavööndis. Endiste paisjärvede põhjad aga soostusid.

Klimaatilised rekonstruktsioonid viitavad kliima üldisele paranemisele varaja keskholotseenis. Lühiajalisi kliima jahenemise perioode esines 8700-8500, 7900-7700, 2000-1000 ja 500-300 a.t. Kliima oli tänapäevasest niiskem 9200 $8800,7800-7600,6500-6300,5800-5200,4600-3900,2400-1600$ ja 800 600 a.t.

\title{
ГОЛОЦЕНОВЫЕ ИЗМЕНЕНИЯ ПРИРОДНЫХ УСЛОВИЙ В ОКРЕСТНОСТЯХ ВИЙТНА, СЕВЕРНАЯ ЭСТОНИЯ
}

\author{
Лейли СААРСЕ, Аннели ПОСКА, Енн КАУП и Атко ХЕЙНСАЛУ
}

Исследована история изменения растительности в голоцене на камовых полях Вийтна и Уку. В раннем голоцене здесь преобладали березовые леса, которые примерно 7600 лет т. н. уступили место смешанным и широколиственным породам. На альварных почвах такая замена обычно происходила уже в бореале. В начале голоцена доля сосновых сообществ была довольно скромной, и лишь за последние 1500 лет сосна значительно расширила ареал своего распространения. Вырубка леса стала практиковаться примерно 4000 лет т. н. и выращивание культурных злаков вблизи камовых полей - 3300 лет т. н., о чем говорит появление пыльцы злаковых в спорово-пыльцевых спектрах.

Изучено также изменение уровня воды в водоемах на примере четырех озер, весьма отличающихся от ранее исследованных трендом изменений. Уровень воды в этих озерах повышался с пребореала до конца атлантической фазы. В результате вода в запруде Ватку достигла уреза примерно 5400 лет т. н., затопила запруженные камовые поля и размыла сыпучие пески в долине, дав начало р. Лообу. Остальные три озера в районе верхнего течения р. Лообу обмелели. Так, уровень воды оз. Линаярв упал на 3 м, оз. Пикаярв - на 3,5 м, оз. Кыверъярв - на 4 м.

Спорово-пыльцевые анализы указывают на благоприятные климатические условия в раннем и среднем голоцене. Непродолжительные периоды похолодания пришлись на 8700-8500, 7900-7700, 2000-1000 и 500-300 годы, а периоды повышенной, по сравнению с теперешним климатом, влажности - на 9200-8800, 7800-7600, 6500-6300, 5800-5200, 4600-3900, 2400-1600 и 800-600 годы. 